\title{
THE COMMODITY OF JUSTICE IN STATES OF EMERGENCY
}

\section{Professor Clive Walker, Director of the Centre for Criminal Justice Studies, University of Leeds.}

Emergency cases arise from extraordinary circumstances and extraordinary laws. Their very existence may be marked by derogation under international law, ${ }^{1}$ while in national law they are quarantined under such labels as "Temporary Provisions" and "Emergency Provisions" 2 and are widely viewed as "Draconian"3 or even "extremely Draconian". 4 How then to achieve justice in such foreboding circumstances? One answer ${ }^{5}$ is that justice cannot be achieved by traditional means alone, and so there has to be an augmentation of justice both by lawyers exploring nontraditional fields and equally by non-lawyers entering the legal fray. Our aim must be to achieve "constitutional governance", 6 a term I have explained elsewhere as including a rights audit, democratic accountability and constitutionalism. ${ }^{7}$ So, the remainder of this article will show how these abnormal forms of intervention are developing, and how they may be viewed, at least in the context of emergency situations, as perhaps inevitable and possibly beneficial.

\section{THE LIMITS OF ADJUDICATION}

The first step in the argument is that legal justice by way of traditional adjudication cannot respond adequately to emergency cases. There may be several reasons for this. They certainly include the difficulties of factfinding and fact-establishment in such cases, as when public interest immunity certificates are issued ${ }^{8}$ or when investigators are met with "walls of silence" by cohesive units of security forces. 9 The sensitive nature of the information in emergency cases has been cited by many reviewers

1 For those pertaining to the UK, see especially Human Rights Act 1998 sched.2.

2 See Prevention of Terrorism (Temporary Provisions) Act 1989; Northern Ireland (Emergency Provisions) Act 1996.

3 H.C. Debs. Vol. 882 col. 35, 25 November 1974, Mr Roy Jenkins.

4 This description was applied by the Taoiseach, Bertie Ahern, to the Offences against the State (Amendment) Act 1998: The Times 20 August 1998 p.1.

5 Others include of course a redesign of the provisions or even their abolition. See C.P. Walker, "Anti-terrorism laws for the future" (1996) 146 New Law Journal $586,657$.

6 Compare: C. Walker, The Prevention of Terrorism in British Law (2nd ed., Manchester: Manchester University Press, 1992) pp.21-22; J.A. Tapia Valdes, "A typology of national security policies" (1982) 9 Yale J. of World Public Order 10 at pp 35, 36.

7 C.P. Walker, "Constitutional governance and special powers against terrorism" (1997) 35 Columbia Journal of Transnational Law 1.

8 See C.P. Walker, with G. Robertson, "Public interest immunity and criminal justice" in C.P. Walker and K. Starmer, Miscarriages of Justice: A Review of Justice in Error (London: Blackstone Press, 1999) chap.8.

9 See McCann v UK, App. no.18984/91, Ser A no.324, (1996) 21 EHRR 97. One response from the Strasbourg institutions has been to alter the burden of proof in such cases: Tomasi v France, App. no.12850/87, Ser. A no. 241-A para.110; Ribitsch v Austria, App. no.18896/91, Ser. A no. 336, para. 34; Aksoy v Turkey, App.no 21987/93, Reports 1996-VI, para.61. 
(and by many judges ${ }^{10}$ ) as an obstacle which blocks more effective judicial intervention: ${ }^{11}$

"It is intelligence information, whose disclosure may involve unacceptable risks. Information which is specific about a person's participation in an act of terrorism may be known to only two or three people. It could, without difficulty, be traced back to its source if it became known to the subject of the exclusion order or to a wider circle of his associates and friends. From this might follow the death of the informant. The flow of information which can lead, and in many cases has led, to convictions in the courts would be endangered."

Next, there may be intimidation - both of individuals who wish to complain or have complained to the legal authorities and of their lawyers. The intimidation may emanate from non-state actors, such as paramilitary groups, ${ }^{12}$ or from state agents. As regards the latter, intimidation is said to have arisen through allegations of intentional collusion between lawyer and paramilitary suspect. No evidence of such collusion has ever been put before a court, nor has any lawyer ever been charged or disciplined as a result of such misconduct. Nevertheless, a Home Office Minister (Douglas Hogg) once hinted at it ${ }^{13}$ and it is alleged that the police often explicitly denigrate specific solicitors to their potential detainee clients so as to deny or defer effective access to independent legal advice and redress. Some of the consequences have allegedly included the murder of two prominent defence solicitors, Pat Finucane, by the Ulster Freedom Fighters in $1989,{ }^{14}$ and Rosemary Nelson, by the Red Hand Defenders in $1999 .{ }^{15}$ Next, there is the difficulty of recognising the bigger picture - in other words, systematic patterns of wrongdoing rather than individual lapses. Finally, the special passion and sensitivity of terrorist cases brings extra problems, including a disinclination on the part of the judges to challenge the executive. Not only are they dealing with national security, but it is national security in a time of perceived crisis. So, the tendency is towards terse, assertive judgments which are deferential to security concerns. ${ }^{16}$

10 But see $R$ v Secretary of State for the Home Department, ex $p$, McQuillan [1995] 4 All E.R. 400.

11 Review of the Operation of the PTA 1974 and 1976 ("Shackleton Report"), (London: Cmnd.7324, H.M.S.O., 1978) para. 52, quoted with approval in $R$ v Secretary of State for Home Affairs, ex parte Stitt The Times 3 February, (1987) (Q.B.D.). See also: L. Lustgarten, and I. Leigh, In From the Cold (Oxford: Clarendon Press, 1994) chap.12.

12 See L. Kennedy, (ed.), Crime and Punishment in West Belfast (Belfast: The Summer School, 1995); M. Matassa, "Rough justice" (1997) 29 Criminal Justice Matters 24-25.

13 HC Debs. Standing Committee B col.508, 17 January 1989.

14 See the Pat Finucane Centre web pages (http://www.serve.com/pfe/); Lawyers' Committee for Human Rights, Human Rights and Legal Defence in Northern Ireland (New York, 1993) chap.2; Report of the International Human Rights Working Party of the Law Society of England and Wales, Northern Ireland: An Emergency Ended? (1995) pp.23-33; ; Report on the Mission of the Special Rapporteur to the United Kingdom of Great Britain and Northern Ireland (E/CN.4/1988/39/Add.4, Geneva, 1998) paras.62-74.

15 The Times 16 March 1999 p. 1

16 See: S. Livingstone, "The House of Lords and the Northern Ireland Conflict" (1994) 57 Modern Law Review 333. 
As well as these particular problems endemic to security situations, there are other difficulties which may be held in common with other attempts to litigate civil liberties issues in the United Kingdom courts by the use of administrative law - at least until the Human Rights Act 1998 comes into full swing. ${ }^{17}$ These include the fact that litigants are forced to pitch their cases around inappropriately hostile, narrowly technical and irrelevant sites, rather than being able to confront the rights issues head on. ${ }^{18} \mathrm{Next}$, no special weight is accorded as such to the right which is under threat. It may be part of English common law, but it certainly does not gain any sanctity by being domesticated in this way and often will seemingly be outweighed by more specific and quantifiable interests in national security. ${ }^{19}$ Next, the courts can only speak about rights reactively and in response to litigation which is "largely a matter of chance." 20 Another problem is that the procedures and remedies in domestic litigation are more geared towards property claims than autonomy claims. As for remedies, "treat me with respect" involves much more imagination on the part of courts than "return my goods" or "compensate me for my injury."

Clearly, domestic judicial review, at least as currently constituted, is unlikely to pick up anything other than the isolated and fairly blatant abuse. The cases are manageable in that they involve an individual and inquiry about that individual, but the judges have not been effective rights auditors. In any event, no matter how adventurous the judges may wish to become, court-rooms have very limited possibilities in English law as the venue for democratic accountability or even the broader aspects of constitutionalism.

Despite all these shortcomings, the focus of a majority of legal commentators for many years has been upon cases arising via traditional adjudication. We would read the judicial runes and pick over their judgments for textual correctness and for signs of liberal or repressive tendencies. Probably the leading analyst of the performance of the Northern Ireland judiciary is Professor Brice Dickson. He has given us some excellent insights into the small and necessarily insulated world of the Northern Ireland judiciary through his books on the legal system in that jurisdiction. ${ }^{21}$ Furthermore, in an important paper in 1992, he analysed the role and performance of the Northern Ireland judges during "The Troubles".22 He found a mixed record, with rather permissive

17 See C. Baker, Human Rights Act 1998 (London: Sweet \& Maxwell, 1999); P. Duffy, S. Grosz, J. Beatson, A Guide to the Human Rights Act 1998 (London: Sweet \& Maxwell, 1999); J. Wadham, and H. Mountfield, Blackstone's Guide to the Human Rights Act 1998 (London: Blackstone Press, 1999). For the first indications of a more robust judicial attitude based on human rights, see $R \mathrm{v}$ D.P.P., ex p. Kebilene (1999) The Times 31 March.

18 The relevant procedural rules are set out at: Rules of the Supreme Court Order 53 (1977) S.I. No. 1955; 1980 S.I. No. 2000); Supreme Court Act 1981 s.31.

${ }^{19} R$ v SSHD, ex p. Brind [1991] 1 AC 696.

20 Lord McCluskey, Law, Justice and Democracy (London: Sweet and Maxwell, 1986) p 5.

21 See B. Dickson, The Legal System of Northern Ireland (3rd ed., Belfast: SLS, 1993) chap.1. See also "Northern Ireland's legal system - an evaluation" (1992) 43 Northern Ireland Legal Quarterly 315.

22 B. Dickson, "Northern Ireland's Troubles and the Judges" in B. Hadfield, (ed.), Northern Ireland: Politics and the Constitution (Buckingham: Open University Press, 1992). See also S. Livingstone, "Policing, Criminal Justice and the Rule of Law" in J. Hayes, and P. O'Higgins, (eds.), Lessons from Northern Ireland (Belfast: SLS, 1990) p 87. 
interpretations in regard to police powers (to arrest or to apply force) but more assertive rulings once the person is in custody and especially where matters of admissibility impact upon the nature of trials and therefore the public's perceptions of judges (for example, confession and "supergrass" evidence). ${ }^{23}$ In summary, the Northern Ireland judges are found to be "pro-Establishment" but that is rightly suggested to be a characteristic shared almost universally by judges and is found to be less pronounced than in the performance of the House of Lords when hearing cases from the Province. ${ }^{24}$ A similar mixed record was the conclusion of a paper by Charles Hill and Simon Lee for the Standing Advisory Commission for Human Rights around the same time. ${ }^{25}$ Taking further the comparison of Northern Ireland and House of Lords judges, Stephen Livingstone, in a paper in 1994,26 dissected the performance of the House of Lords and complains of rather short, technical judgments which simply adopt the world view of the security forces. ${ }^{27}$. More recently, Brice Dickson has launched another probe into the judicial firmament by asking, perhaps as an indicator of pro-Establishment fixity, to what extent have the Northern Ireland judiciary been influenced by the European Convention and how they have used it in their judgments. ${ }^{28}$ Here, the picture is less dynamic, and he feels that they have been less adventurous than their uninspiring English counterparts.

To summarise, adjudication has continuing importance as central to the role of the judiciary in emergency cases. It inherently recognises the importance of individuality and determines its rightful place in our society. Additionally, the judges, unlike politicians, have to give a dispositive answer to the litigants appearing before them, and the result is to accord human interest and drama to their decisions which bring with them attention and respect. On another level, the courts can also be used as an important forum, alternative to the usual political channels, for challenging the priorities and discretions of the government and its agents. At the same time, the critics have pointed to a failure to exploit this position of authority on behalf of the individual against the state, and so they have tended to doubt the transformative impact of the hundreds of judgments from Northern Ireland over nearly three decades of securitybased disputes. So, Stephen Livingstone sees the judges as at best "potential assistants rather than essential guardians of ...rights." 29

${ }^{23}$ See also G. Hogan, and C.P. Walker, Political Violence and the Law in Ireland (Manchester: Manchester University Press, 1989); S. Greer, Supergrasses (Oxford: Clarendon Press, 1995), J. Jackson and S. Doran, Judge without Jury (Oxford: Clarendon Press, 1995).

24 B. Dickson, "Northern Ireland's Troubles and the Judges" in B. Hadfield, (ed.), Northern Ireland: Politics and the Constitution (Buckingham: Open University Press, 1992) pp 136, 144.

25 "Without fear or favour? Judges and human rights in Northern Ireland" in SACHR, 18th Report (1992-93 H.C. 739) Annex B.

26 S. Livingstone, "The House of Lords and the Northern Ireland Conflict" (1994) 57 Modern Law Review 333.

27 Ibid at p.350. For the latest case, see O'Hara v Chief Constable of the RUC [1997] 1 Cr App R 447.

28 "The European Convention in Northern Ireland Courts" [1996] European Human Rights Law Review 496. For the performance of English judges, see M. Hunt, Using Human Rights in English Courts (Oxford: Hart Publishing, 1997)

29 S. Livingstone, "The House of Lords and the Northern Ireland Conflict" (1994) 57 Modern Law Review 333 at p.360. 
Yet, it would be misleading to think that the judges have achieved nothing of significance. They have positively secured some important changes, such as the opening up of access to solicitors, ${ }^{30}$ though one can always think of some equally negative series of cases such as those on coroners' powers. ${ }^{31}$ And there is undoubtedly a failure to respond to a larger picture, such as when the Northern Ireland Court of Appeal solemnly sat through case after case in 1976 and thereafter in which confessions were disputed but without any wider inquiry into what was happening at the Castlereagh Holding Centre, the eventual investigation into which was far more attributable to investigative journalism than inquisitorial judicialism. ${ }^{32}$ They also failed to act with sufficient robustness to prevent the changes to the "right to silence" in 1988, ${ }^{33}$ but ironically did block the use of judicial officers to review detentions under section 14 of the Prevention of Terrorism Act, an outcome which would arguably have safeguarded liberty and avoided a more permissive derogation in international law. ${ }^{34}$ In sum, all of the problems outlined earlier have applied here and have tended towards the marginalisation of judicial adjudication as a force for change or constitutional governance in emergency cases.

\section{AN AUGMENTATION OF JUSTICE BY LAWYERS}

Can lawyers compensate for the limits on traditional adjudication by the utilisation of more varied techniques to achieve justice? This phenomenon in its widest sense is marked by the number of lawyers in the House of Commons - more than ever and more prominent than ever. Undoubtedly, the personal and professional backgrounds of legislators and politicians is of significance, but what this paper seeks to explore is the choice and deployment of lawyers on tasks directly relating to legal justice but which have significant political elements to them and are far removed from traditional litigation.

\section{EXTRA-CURIAL INQUIRIES INTO JUSTICE ISSUES}

Official commissions which involve taking lawyers outside the court-room are nothing new, and Northern Ireland has always been an especially fertile ground for judge-based inquiries, albeit by judges from other British jurisdictions. The trend was established early in the history of the "Troubles" with the Cameron Report ${ }^{35}$ and then the Scarman Report, ${ }^{36}$ both of which were very wide-ranging inquiries into the origins of violence and responsibilities for it. Subsequent exercises have tended to

30 See $R$. v Harper [1990] 4 N.I.J.B. 75; Re Duffy [1991] 7 NIJB 62; Re McKenna (1992) 3 BNIL n.54; $R$ v Chambers [1994] 2 BNIL n.58; In re Russell [1996] 9 BNIL n33; In re Begley (1996) 5 BNIL n39; John Murray v UK, Appl. no. 18731/91, Ser.A vol. 300-A, (1996) 22 EHRR 29.

31 McKerr v Armagh Coroner [1990] 1 All ER 865.

32 P. Taylor, Beating the Terrorists? (London: Penguin, 1980).

33 Criminal Evidence (N.I.) Order 1988 S.I. 1987. See: J.D. Jackson, "Curtailing the right to silence" [1991] Criminal Law Review 404, "Inferences from silence" (1993) 44 Northern Ireland Legal Quarterly 103; "Interpreting the silence provisions" [1995] Criminal Law Review 587; John Murray v UK, Appl. no. 18731/91, Ser.A vol. 300-A, (1996) 22 EHRR 29.

34 See C. Walker, The Prevention of Terrorism in British Law (2nd ed., Manchester: Manchester University Press, 1992) chap.8.

35 Disturbances in Northern Ireland. Report of the Commission appointed by the Governor of Northern Ireland (Belfast: Cmd. 532, 1969).

36 Government of Northern Ireland. Violence and Civil Disturbance in Northern Ireland in 1969. Report of a Tribunal of Inquiry (Belfast: Cmd. 566, 1972). 
be more specific and justice-related, as the writing of political history by judges was not only disputed but also lacked impact. So, later inquiries were generally narrower, but they were not necessarily any less controversial. These include, for example, Lord Widgery's inquiry into Bloody Sunday ${ }^{37}$ and the inquiries by Lord Parker and Judge Harry Bennett's inquiry into army and police interrogation practices. ${ }^{38}$ But most have been about the design of the emergency provisions themselves, ranging from the seminal Diplock Report, ${ }^{39}$ to the latest blue-print for a more permanent code by another Lord of Appeal in Ordinary, Lord Lloyd. ${ }^{40}$ In between times, a regular succession of inquires, all by lawyers, have been published. ${ }^{41}$

By comparison, the Northern Ireland judiciary have performed such tasks relatively infrequently. Instances include Lord Justice McDermott who chaired the Working Party on Public Prosecutions in 1971.42 In addition, Lord Chief Justice Lowry was part of the Anglo-Irish Law Enforcement Commission looking into matters of extradition and cross-border justice in $1974 .{ }^{43}$ However, it is clear that the British experience described above is not out of line with overseas experience, ${ }^{44}$ and so one might infer some

37 Report of the Tribunal appointed to inquire into the events on Sunday 30 January 1972 which led to loss of life in connection with the procession in Londonderry on that day (1971-72 H.C. 220).

38 Report of the Committee of Privy Counsellors appointed to consider authorised procedures for the interrogation of persons suspected of terrorism ("Parker Report”) (London: Cmnd. 4901, H.M.S.O., 1972); Report of the Committee of Inquiry into Police Interrogation Procedures in Northern Ireland ("Bennett Report") (London: Cmnd. 9497, H.M.S.O., 1979).

39 Report of the Commission to consider legal procedures to deal with terrorist activities in Northern Ireland (London: Cmnd. 5185, H.M.S.O., 1972).

40 Inquiry into Legislation against Terrorism (London: Cm. 3420, H.M.S.O., 1996).

41 See "Gardiner Report": Report of a Committee to consider, in the context of civil liberties and human rights, measures to deal with terrorism in Northern Ireland (London: Cmnd. 5847, H.M.S.O., 1975); "Baker Report": Review of the Operation of the Northern Ireland (Emergency Provisions) Act 1978 (London: Cmnd. 9222, H.M.S.O., 1984); "Colville Report": Review of the Operation of the Prevention of Terrorism (Temporary Provisions) Act 1984 (London: Cm. 264, H.M.S.O., 1987); "Colville Report": Review of the Northern Ireland (Emergency Provisions) Acts 1978 and 1987 (London: Cm.1115, H.M.S.O., 1990).

42 Belfast: Cm. 554, 1971.

43 See C. Campbell, "Extradition to Northern Ireland" (1989) 52 Modern Law Review 585; G. Hogan, and C. Walker, Political Violence and the Law in Ireland (Manchester: Manchester University Press, 1989) chaps. 14, 15; H. Delaney, and G. Hogan, "Anglo-Irish extradition viewed from an Irish perspective" [1993] Public Law 93; G. Gilbert, Transnational Fugitive Offenders in International Law (Martinus Nijhoff, The Hague, 1998) chap.6.

44 See "Hope Report": Royal Commission on Intelligence and Security (4th Report PP. 249 (Cth), Canberra, 1977); “O'Brian Report": Report of the Committee to recommend certain safeguards for persons in custody and for members of An Garda Siochana (Prl. 7158, Dublin 1978); "McDonald Commission": Report of the Commission of Inquiry concerning certain activities of the Royal Canadian Mounted Police, Freedom and Security (2nd Report, Ottowa, 1981); "Rabie Report": Report of the Commission of Inquiry into Security Legislation (RP90/1981, Pretoria, 1981); "Landau Report": Report 
reluctance on the part of Northern Ireland lawyers to accept such highprofile appointments from their already exposed position as public servants. ${ }^{45}$ British judges seem less inhibited, and this characteristic continues with Lord Saville accepting a commission to reinquire into Bloody Sunday in 1998.46

\section{STANDING INQUIRIES}

This task of inquiring into the working of the law outside the context of litigation has also shaded into a potentially more substantial role - the standing inquiry. This may differ in at least two respects which relate to its continuous nature. First, there is a tendency to add a superintendence role - in this way, the inquirer is not simply pronouncing on past events but may be able to shape them as they happen. Second, the fact that the exercise is repeated allows for more dialogue and negotiation than with a once and for all pronouncement. This feature may allow for extra pressure to be exerted as earlier official objections to the reviewer's proposals are specifically traduced.

In the emergency legislation field, the longest-established standing inquiries are the periodical annual reviews which have been conducted since 1984 by Sir Cyril Philips (the sole non-lawyer in the list and also the person who had the shortest period in office), Viscount Colville and John Rowe. Doubts may be raised concerning the remit of these reviews ${ }^{47}$ and even the personal competencies of the reviewers. Few have provided evidence of any deep thought to issues of principle or structural reform, but instead proceed with vague notions of balancing both security and rights. In addition, they almost always are handicapped with the assumption that special powers are necessary and thereby that normal laws are inadequate or cannot be adapted. Their evidence-gathering is far from perfect. When it is available, the most influential information arrives in secret from security forces and is not disclosed by the reviewer, so there is no open debate or exchange. And the manner of publication of the reviews is hardly calculated to capture public or Parliamentary attention. They have mainly delivered useful, though often rather technical, alterations, which should at least be credited in terms of an audit in protection of rights. For example, changes to the residence exemption period in respect of exclusion, which had been twenty years until reduced to just three years on the recommendation of the Jellicoe Report, ${ }^{48}$ is certainly a worthy achievement. Only rarely have there been radical reforms and suggestions - including the abolition of exclusion. ${ }^{49}$ And it is also noticeable that the focus of the reviews has mostly been in the direction of the treatment of individual rights, so the broader issues of democratic accountability and constitutionalism remain unattended.

of the Commission of Inquiry into the methods of investigation of the General Security Service regarding hostile terrorist activity (Jerusalem, 1987); Commission chaired by Judge Richard Goldstone (The Independent, 29 May 1992 p.12).

45 A list of deaths is provided at HC Debs. vol.331, col.52 10 May 1999.

46 The Times, 30 January 1998, p.1; http://www.bloody-sunday-inquiry.org.uk/. The other commissioners are Sir Edward Somers and William Hoyt.

47 C. Walker, The Prevention of Terrorism in British Law (2nd ed., Manchester: Manchester University Press, 1992) p.37.

48 Jellicoe Report, paras.181, 182.

49 See C.P. Walker, "Constitutional governance and special powers against terrorism" (1997) 35 Columbia Journal of Transnational Law 1. 
As to what would be in outline an effective executive internal review system, some of the following features should be included. The first concerns the personnel conducting the review. There is a periodical need for an infusion of new blood into the process. Those who stay seem to become complacent or discouraged, while officially presented versions of reality tend eventually to become persuasive or at least immutable. ${ }^{50}$ This feature might best be achieved by the appointment of a panel so that difficulties caused by inexperience of new members can equally be minimised but at the same time there is a constant influx of fresh thinking.

Secondly, the review must be principled. So as to encourage the widest discussion possible, the legislature should set the necessary standards on which each part of any special legislation can be judged as necessary and proportionate to the emergency.

Thirdly, the review must be adequately resourced. The codes dealing with political violence are now a multi-faceted legislation whose complexity and range have grown enormously over two decades. Effective review can only be achieved by individuals working full-time and continuously. Resourcing also entails express statutory powers of investigation, akin to those of the Parliamentary Commissioner for Administration. ${ }^{51}$ Reviewers should be enabled to look behind the dossier of papers presented to the Home Secretary about a candidate for exclusion; they should have access to filing cabinets and databases and should be able to interrogate members of the police and security services and not just hapless excludees.

Fourthly, reviews must be more firmly tied to the legislature so as to encourage democratic accountability. This feature requires the clearer dissemination of information by the reviewers so as to facilitate reasoned debate and to engage its attention in a constructive manner. There is also a need for a more structured linkage between reviewers and Parliament. This relationship has been neglected by the legislative reviewers, who are effectively appointed by, and report back to, a Secretary of State - not even to the Lord Chancellor. ${ }^{52}$

A more recent example of a standing inquiry of this kind is the appointment of the Independent Commissioner for the Holding Centres. ${ }^{53}$ The main functions of the Commissioner are to "observe, comment and

50 One might consider by way of evidence the record of the main reveiws of the PTA. In the bodies of their reports,the Shackleton Report in 1978 managed 160 paragraphs of text (49 A5 pages), the Jellicoe Report in 1983 produced 233 paragraphs (96 A5 pp.), and the Colville Report in 1987 amounted to 214 paragraphs (59 A4 pp.). The depth of the last report is especially disappointing given that the PTA had grown considerably in length and complexity between 1978 and 1987, as had the case-law and practices surrounding it.

51 See the Parliamentary Commissioner Act 1967 s.8.

52 Despite its firmer statutory footing, a link with Parliament is not even a feature of the more independent and permanent Standing Advisory Commission on Human Rights, which was set up under the Northern Ireland Constitution Act 1973 in Northern Ireland. The political marginalisation of this body may be one result. See: P. Maguire, "The SACHR 1973-80" (1981) 32 Northern Ireland Legal Quarterly 31. The SACHR has now been replaced by the Northern Ireland Human Rights Commission (Northern Ireland Act 1998 ss.68, 72) which does have some institutional links to the Assembly.

53 C. Walker, and B. Fitzpatrick, "The Independent Commissioner for the Holding Centres: a review" [1998] Public Law 106, "Holding centres in Northern Ireland, the Independent Commissioner and the rights of detainees" [1999] European Human Rights Law Review 27. 
report upon the conditions under which persons are detained in Holding Centres" within Northern Ireland and to "provide further assurance to the Secretary of State that persons detained in Holding Centres are fairly treated and that both statutory and administrative safeguards are being properly applied" ${ }_{54}$ His Annual Reports cover visits made by him and his Deputy to the Holding Centres. During the visits, interviews and discussions are conducted where possible and appropriate with detainees, medical staff, solicitors and with uniformed and non-uniformed officers and the ancillary staff. A concession made in 1994 was to allow the Commissioner to sit in on interviews, setting aside concerns that the Commissioner could later be called or cited as a witness to the process of interviewing by the police or that his presence might be off-putting to a suspect. $^{55}$ So, we see here the beginnings of some superintendence. But despite this concession, the work of the Commissioner is mainly policyoriented and not concerned with the resolution of individual complaints or cases.

Amongst his achievements, the Commissioner has damned Castlereagh altogether on five occasions, with continuing vigour, and, one senses from the Reports, mounting exasperation. ${ }^{56}$ In terms of setting the agenda, the Commissioner has been very successful in his campaign and far more vigorous and courageous than other national reviewers. ${ }^{57} \mathrm{He}$ has forced the issue to be considered seriously, and he has also succeeded in establishing the argument in principle that to treat suspects in this way is, at least in the $1990 \mathrm{~s}$, wholly unacceptable. More generally, the Commissioner does impart distinctive qualities of expertise and also experience and authority through presence and attention to detail. On balance, the concentration of oversight upon one vital element of the special criminalisation process has been very worthwhile, especially because of the remarkable inventiveness and fearless independence (from government, the police, and professional and established pressure groups in Northern Ireland) that Sir Louis Blom-Cooper has brought to the office. Nevertheless, criticisms can be voiced as to how the Commissioner has at times chosen to direct his fire. In the light of this overall assessment, there would seem to be a strong case for regularising ${ }^{58}$ and extending the office - the most obvious candidates for extra scrutiny would be the principal detention facility of the Metropolitan Police's Anti-terrorist Branch, namely Paddington Green Police Station, and also the holding facilities at the main ports such as Liverpool and Stranraer. Finally, and more broadly, one might consider that as special regimes develop not only for suspect terrorists but also for other categories of serious criminality, such

54 See Independent Commissioner for the Holding Centres, First Annual Report (1994) pp.3-4.

55 Second Annual Report (1995) p.39, Third Annual Report (1996) p.39. This was advocated both by the Commissioner and the Standing Advisory Commission on Human Rights ("SACHR"), 19th Report (1993-94 HC 495) chap. 2 para.29 and the Report to the UK Government on the Visit to Northern Ireland carried out by the European Commission for the Prevention of Torture etc 1993 (CPT/Inf (94) 17, 1994) para. 101.

56 But the Sixth Annual Report (1999, p.4) accepts that there has been some physical improvement.

57 An exception to the silence of others has been the SACHR, 20th Report (199495 HC 506) chap 2 para.25, 21st Report (1995-96 HC 467) chap 3 para.20.

58 A form of judicial appointment might also tie in with the decision to extend the detention: SACHR, 16th Report (1990-91 HC 488) para. 2.15. Regularisation also entails express statutory powers of investigation, and formal ties to the legislature. 
as serious fraud or sex offences, there may be an argument for independent expertise, not necessarily by one and the same Commissioner, to be applied in these other directions. A fragmenting criminal justice system, which especially builds upon police surveillance and intervention rather than community testimony and involvement, requires innovative forms of superintendence which neither the police nor the community can adequately supply.

Overall, a picture emerges whereby these forms of standing inquisition seem to provide an important model of judicial or at least lawyerly superintendence of problematic aspects of the emergency regime and indeed the criminal justice system. However, as is the British way, they are often characterised in terms of their constitution by "ad hocery" - none has been set up with any formality or with sustained thought as to objectives, relations and outcomes. Nevertheless, inspection is an important aspect of accountability, and one wonders whether more could be learnt from other jurisdictions in which this technique is longer and better established. One example is the US Federal Office of Inspector General which oversees the CIA under the National Security Act of $1947,,^{59}$ as well as the dozens of other Inspectors General set up in 1978 and thereafter. ${ }^{60}$ Certainly the model of standing inspections in this way has proven far less controversial than the more occasional office of Independent Counsel under the Ethics in Government Act of 1978, as amended by the Independent Counsel Reauthorization Acts of 1987 and 1994 (collectively "the Ethics Act"). ${ }^{61}$ That legislation provides for the appointment, by a Special Division of the United States Court of Appeals for the District of Columbia Circuit on the application of the Attorney General, of Independent Counsels to investigate and, if appropriate, prosecute specified high-ranking government officials for violations of federal criminal laws. Under section 591(b), the Attorney General may request that an independent counsel be appointed when her preliminary investigation discloses that certain listed individuals in the executive branch of government may have violated the law. These individuals include the President and Vice President, the Director of Central Intelligence, Commission of Internal Revenue, and high-ranking Executive Office officials. The Act has certainly provided for the involvement of lawyers, the most prominent office-holder of recent times being Kenneth Starr, ${ }^{62}$ in an inquisition of executive deeds and misdeeds,

5950 USC s.403q (an amendment passed in 1988 to the original Act; the office came into being in 1990). See Boren, D.L., "The Winds of Change at the CIA" (1992) 101 Yale Law Journal 853.

60 Inspector General Act 1978 (5 USC app.3). The Act set up Offices in 12 major federal agencies. The Act was later extended in 1988 to most federal and regulatory agencies. See W.S. Fields, and T.E. Robinson, "Legal and functional influences on the objectivity of the Inspector General audit process" (1993) 2 George Mason Independent Law Review 97.

61 See generally 28 U.S.C. ss.591-599 (1994 \& Supp. 1995). The legislation was held to be constitutional in Morrison v. Olson, 487 U.S. 654 (1988). See R.G. Solloway, "Note, The institutionalized wolf: an analysis of the unconstitutionality of the Independent Counsel provisions of the Ethics in Government Act of 1978" (1988) 21 Indiana Law Review 955.

62 See Referral to the United States House of Representatives pursuant to Title 28, United States Code, $\S 595(c)$ Submitted by the Office of the Independent Counsel, (http://icreport.house.gov/icreport/, 1998). See further In the matter of a charge of judicial misconduct or disability (1994) 39 F.3d 374; United States of America v Tucker, Marks and Haley (1995) 898 F. Supp. 654; United States of America v McDougal, Tucker and McDougal (1995) 906 F. Supp. 499; 
and it does secure the reduction of executive dominance over the nature and conduct of inquiries into its own affairs. ${ }^{63}$ But it is arguable that a permanent inspector is more likely to achieve the institutionalisation of good ethical and legal observances. Conversely, investigations by Independent Counsel have been criticised as too wide-ranging both in scope and time and too often engulfed in a climate of politicisation; as a result, the legislation will not be extended beyond 30 June $1999 .{ }^{64}$

\section{POLITICAL INQUISITION BY LAWYERS}

It is the utilisation of lawyers as political actors or catalysts which is of interest here. Perhaps the finest example of the moment is the Lord Chancellor, Derry Irvine, whose curriculum vitae includes:

- membership of the executive. As head of the Lord Chancellor's Department, he deals with matters such as access to justice, law reform process, the appointment of virtually all the professional and lay judiciary, the supervision of the efficient and effective operation of the courts. ${ }^{65} \mathrm{He}$ is also a senior Cabinet minister and chairs the following Cabinet committees: Ministerial Sub-Committee on House of Lords Reform; Ministerial Sub-Committee on Freedom of Information; ${ }^{66}$

- membership of the legislature, acting as Speaker of the House of Lords as well as representing the government on legal matters in the House of Lords;

- judicial office. He is the head of the judiciary and can sit in the Appellate Committee of the House of Lords (and did so for the first time in April 1998). ${ }^{67}$

Turning back to Northern Ireland, who can possibly hope to match Lord Irvine in his accumulation of power? One rival might be George Mitchell, the chair of the Decommissioning Commission ${ }^{68}$ and then of the peace

United States of America v Hubbell (1998) 11 F. Supp. 2d 25; In the matter of a charge of judicial misconduct or disability (1998) 141 F.3d 333.

63 See C. Levin, "The Independent Counsel Statute: A Matter of Public Confidence and Constitutional Balance" (1987) 16 Hofstra Law Review 11; J.M. Kelly, and J.P. McEntee, "The independent counsel law: is there life after death?" (1993) 8 St. John's Journal of Legal Commentary 561; P.W. Rodino, Jr., "The case for the independent counsel" (1994) 19 Seton Hall Legislative Journal 5.

${ }^{64}$ For criticisms, see "The Independent Counsel process: is it broken and how should it be fixed?" (1997) 54 Washington \& Lee Law Review 1515; K. Clark, "Toward More Ethical Government: An Inspector General for the White House" (1998) 49 Mercer Law Review 553; C.R. Sunstein, "Bad Incentives and Bad Institutions" (1998) 86 Georgetown Law Journal 2267; N. Bravin, "Is Morrison v Olson still good law?" (1998) 98 Columbia Law Review 1103; D.C. Smaltz, "The Independent Counsel: A View From Inside" (1998) 86 Georgia Law Journal 2307; J. Reno, Evidence to the House Judiciary Subcommittee (http://www.usdoj.gov/dag/ictestimonydag.htm, March 1999).

65 See http://www.open.gov.uk/lcd/lcd-defr.htm.

66 See http://www.open.gov.uk/co/cabcom/index.htm.

67 Boddington v British Transport Police [1998] 2 WLR 639.

68 See Report of the International Body on Decommissioning (http://britaininfo.org/bis/nireland/mitchell.htm, 1996). 
talks leading to the "Good Friday" Agreement, ${ }^{69}$ though it is his capacity as ex-Senator and political friend of the United States President which have probably been the vital attributes favouring appointment rather than his legal training..$^{70}$ However, a good example of a relevant legal actor in connection with Northern Ireland concerns the involvement in terms of political justice of Lord Chief Justice Lowry. Robert Lowry, the exUnionist Government Attorney General, was Chief Justice between 1971 and 1989 and therefore by this accident of timing was arguably by far the most important ever Supreme Court judge in the history of Northern Ireland. But in addition to his normal judicial work, he chaired the Constitutional Convention which sat between 1975 and $1976^{71}$ and, rather like Senator Mitchell, it is clear Lord Lowry was not simply a gavelbasher but did orchestrate to some extent the behind-the-scenes negotiations. $^{72}$

\section{AN AUGMENTATION OF JUSTICE BY NON-LAWYERS}

There may be wider senses in which justice has been harmed in emergency situations than can be represented or even understood by lawyers. One response must be action by other branches of the state which "have the responsibility to ensure that our executive, legislative and judicial branches function responsibly." "73 But the response here in mind involves more than the full force of separate branches of government ${ }^{74}$ and necessarily entails some interplay. As a result, just as lawyers are to take on hybrid legal/political tasks, so non-lawyers must engage with legal justice.

A leading example is the Truth and Reconciliation Commission of South Africa. ${ }^{75}$ This principally comprised non-lawyers and has been chaired by

69 British Irish Agreement reached in the multi-party negotiations (London: Cm.3883, Stationery Office, 1998).

70 For his appointments to the Decommissioning Commission (see Report of the International Body on Decommissioning (1996)) and then the talks process discussing the frameworks for Northern Ireland (see Northern Ireland Office, Frameworks for the Future (London: Cm. 2964, H.M.S.O., 1995)), see The Times, 30 November, 1995 pp.1-3, (1996) The Times, 5 June, 1996 p.2, 13 June p.2.

71 See the Northern Ireland Constitutional Convention (1975-76 HC 1).

72 B. Dickson, "Northern Ireland's Troubles and the Judges" in B. Hadfield, (ed.), Northern Ireland: Politics and the Constitution (Buckingham: Open University Press, 1992) p.133.

73 C. Blakesley, "Terrorism, Law and Our Constitutional Order" (1989) 60 University of Colorado Law Review 471 at p.501. See also: D.G. Barnum, J.L., Sullivan, and M. Sunkin, "Constitutional and Cultural Underpinnings of Political Freedom in Britain and the United States (1992) 12 Oxford Journal of Legal Studies 362.

74 See C.P., Walker, "Constitutional Governance and Special Powers Against Terrorism" (1997) 35 Columbia Journal of Transnational Law 1.

75 See Promotion of National Unity and Reconciliation Act 1995 (no.34); http://www.truth.org.za/. See Azapa v President of RSA 19968 BCLR 1015 (CC); I. Liebenberg, "The Truth and Reconciliation Commission in South Africa" (1996) 11 SA Public Law 123. Its final report has now been delivered (see http://www.truth.org.za/final/index.htm) amidst considerable controversy and litigation (see The Times, 30 October 1998 p.16). For examples in other jurisdictions, see: P.B. Hayner, "Fifteen Truth Commissions - 1974-1994" (1994) 16 Human Rights Quarterly 597. 
the Archbishop Desmond Tutu, though its Committee on Amnesty consisted of members of the judiciary. Without going into the details of this complex foray into political and social reconstruction, which it is dangerous to deconstruct from its specific setting, it may be asked why a body of this kind was felt to be necessary. In short, it was needed in view not only of the difficulties likely to be encountered by traditional adjudication - especially in the form of prosecutions of ex-members of the security forces - but also because such a judicial based process cannot deliver holistic justice in emergency settings: "Reconciliation requires not only individual justice, but also social justice." 76 The argument is not that prosecutions are inimical to peace and have no part to play. They are often demanded by victims or families of victims who view truth and reconciliation as "an insult" and a poor substitute for a "proper court of justice". ${ }^{77}$ Prosecutions do produce knowledge of events and apportion blame in a precise manner so as to separate collective guilt or innocence from individual guilt or innocence. ${ }^{7}$ But the sole reliance upon this mechanism of the legal justice system fails to recognise the wider and more radical interests of restorative justice. ${ }^{79}$

Some of these wider issues have been addressed by the forms of inquiry conducted by the Truth and Reconciliation Committee. To give one example, the Reparation and Rehabilitation Committee took account of five distinct categories of reparation: ${ }^{80}$

"Redress which is the right to fair and adequate compensation;

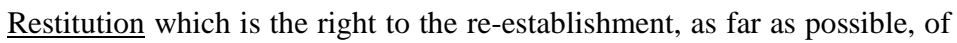
the situation that existed for the beneficiary prior to the violation;

Rehabilitation which is the right to the provision of medical and psychological care and fulfilment of significant personal and community needs;

Restoration of dignity which could include symbolic forms of reparation; and

Reassurance of non-repetition which includes the creation of legislative and administrative measures, which contribute to the maintenance of a stable society and the prevention of the re-occurrence of human rights violations."

76 Final Report, vol.1 chap.5 para.52.

77 Statement by Ntsiki Biko, widow of Steve Biko, in "Wounded Nations, Broken Lives: Truth Commissions and War Tribunals (1996) 25 Index on Censorship Sept/Oct at p.68.

78 J. Mendez, "Accountability for Past Abuses" (1997) 19 Human Rights Quarterly 255 at p. 277.

79 See W., Cragg, Practice of Punishment : Towards a Theory of Restorative Justice (London: Routledge, 1992); M. Wright, Justice for Victims and Offenders : a restorative response to crime (2nd ed, Winchester : Waterside Press, 1996).

80 Truth and Reconciliation Commission, Proposed Policy for UIR and Final Reparation (1997) para.4.1. These were reduced to four headings (but covering much the same concepts) in the Final Report, vol.5 chap.5 paras.24-32: urgent interim reparation, individual reparation grants, symbolic reparation, community rehabilitation and institutional reform. Compare J. Mendez, "Accountability for Past Abuses" (1997) 19 Human Rights Quarterly 255 at p.261; JUSTICE, Victims in Criminal Justice (London, 1997). 
Redress and restitution involving financial restitution for the wrongfully imprisoned or abused are at the core of the justice mechanisms that exist in the United Kingdom. However, there is no attempt at personal or social rehabilitation, while the process of dealing with claims almost seems counter-productive in achieving the restoration of dignity. It has certainly not included any grand gestures of apology or generosity when we think of the likes of the Birmingham $6 .^{81}$ Perhaps the greatest failure, however, is to secure a reassurance of non-repetition either in regard to miscarriages of justice in England or through a full inquiry into disputed events during the conflict in Northern Ireland since 1969. This ultimate goals of accounting for the past and signalling and securing change are at the heart of the South African Commission. According to the preamble of the parent Act:

"...it is deemed necessary to establish the truth in relation to past events as well as the motives for and circumstances in which gross violations of human rights have occurred, and to make the findings known in order to prevent a repetition of such acts in future..."

These objectives are not only of importance as an aspect of reparation to the victim of a miscarriage but also, of course, to the strengthening of societal institutions as a whole. ${ }^{82}$ Yet, the truth has never been established or even fully investigated in many of the major miscarriage cases in England, so it is difficult to see how one can be sure that the reforms which have taken place address the real problems. And prosecutions have been a particular failure in this respect, since no successful prosecution of abusive police officers has ever been brought, a record from which one can hardly draw deterrence or messages for the future. One cannot realistically now expect the Criminal Cases Review Commission to take on this separate agenda, ${ }^{83}$ but one would hope that for the future the Commission will be prepared to make thematic inquiries and recommendations where it recognises patterns of abuse or error.

Equally, aside from the important inquiry currently being conducted by Lord Saville into Bloody Sunday, there are no plans either in the Good Friday Agreement of 1998 or elsewhere to reopen other incidents of disputed deaths or shootings in Northern Ireland. Towards the end of the period of open conflict, Sir Kenneth Bloomfield, appointed as "Victims Commissioner," did consider the possibility in his report, We Will Remember Them ${ }^{84}$ However, he resisted the idea of a commission on the South African model, fearing that "unhappily, 'truth' can be used as a

${ }^{81}$ Far from an apology, some prominent public figures have continued to cast doubt on the innocence of those released, including Lord Denning (see The Times 23 August 1990) and David Evans (see The Times 10 July 1998). For the forms of remedy available in English law, see N. Taylor and J. Wood, "Victims of miscarriages of justice" in C.P. Walker, and K. Starmer, Miscarriages of Justice: A Review of Justice in Error (London: Blackstone Press, 1999) chap.12.

82 See J. Zalaquett, "Balancing Ethical Imperatives and Political Constraints" (1992) 43 Hastings Law Journal 1430; J. Mendez, "Accountability for Past Abuses" (1997) 19 Human Rights Quarterly 255.

83 The CCRC was established by the Criminal Appeals Act 1995. See C. Mullin, "Miscarriages of Justice in the UK" (1996) 2(2) Journal of Legislative Studies 8 at p.12.

84 (Belfast: Northern Ireland Office, 1998). The Report notes (paras.2.4, 2.6) that there had been 3585 deaths attributable to the "Troubles" from 1 January 1970 to 3 December 1997 in Northern Ireland, plus 119 in England. 
weapon as well as a shield" 85 and therefore suggesting that it would be appropriate only as part of a wide-ranging peace process which, at the time of his Report (published in May 1998) and indeed since that time, has yet to tackle the issue. ${ }^{86}$ Indeed, the Good Friday Agreement looked towards the Victims Commissioner (and no other mechanism) to deliver the substantive ideas for reform, ${ }^{87}$ though a few have subsequently emerged outside of his agenda. ${ }^{88}$ The Bloomfield Report did contain some useful ideas, including: a review of the criminal injuries compensation system (which has since been established under Sir Kenneth Bloomfield himself); 89 a recognition of the need for advice and counselling as well as an official representative and a better coordinated approach within government ${ }^{90}$ (satisfied by the appointment of one of the Northern Ireland Office team as Minister for Victims ${ }^{91}$ ); and action to deal with the disappeared, exiled and displaced, ${ }^{92}$ since given shape by the Northern Ireland (Location of Victims' Remains) Act 1999. But a significant portion of the detail, and one senses enthusiasm, of the Report is directed towards appropriate monuments and commemorations of the dead - in other words, the bringing of solace rather than justice to the living. ${ }^{93}$ Furthermore, there is little grounding in any kind of principle - the display

85 We Will Remember Them (Belfast: Northern Ireland Office, 1998) para.5.37.

86 But even after a comprehensive settlement, the limited healing power of reconciliation through truth may be illustrated by the attempts to extradite General Pinochet; see $R v$ Bow Street Stipendiary Magistrate, ex p. Pinochet Ugarte (No.3) (1999) The Times 25 March.

87 See "Rights, Safeguards and Equality of Opportunity" paras.6.11-6.13. The short Northern Ireland Office paper, Restorative Justice, issued around the same time in 1998 does not consider the problems arising from political violence, though restorative justice is part of the agenda of the Criminal Justice Review Group (see: Review of the Criminal Justice System in Northern Ireland, http://www.nio.gov.uk/review.pdf, and Progress Report, 1999, p.6).

88 Tangible measures which have been taken include $£ 5 \mathrm{~m}$ allocated to the Victims Liaison Unit of the Northern Ireland Office (with $£ 1 \mathrm{~m}$ for the Northern Ireland Memorial Fund) (The Times, 13 August 1998 p.2), and the rights of victims to information in section 15 of the Northern Ireland (Sentence) Act 1998:

" (1) The Secretary of State shall provide a statement under this section about a person if he receives a written request to do so and he believes-

(a) that the person about whom the statement is sought is serving a sentence of imprisonment in Northern Ireland for a fixed term of at least five years or for life,

(b) that the sentence was passed in Northern Ireland for a qualifying offence, and

(c) that the person requesting the statement, or a member of his family, was a victim of the offence for which the sentence was passed."

Under the Northern Ireland (Location of Victims' Remains) Act 1999 s.5(2), relatives may be kept informed by the Independent Commission for the Location of Victims' Remains.

89 We Will Remember Them (Belfast: Northern Ireland Office, 1998) para.5.11. For the further study, see The Times, 1 October 1998 p.2.

90 We Will Remember Them (Belfast: Northern Ireland Office, 1998) paras.5.18, 5.28 .

91 See The Times, 14 May 1998 p.1.

92 We Will Remember Them (Belfast: Northern Ireland Office, 1998) paras.5.38, 5.39.

93 We Will Remember Them (Belfast: Northern Ireland Office, 1998) chaps.4, 6, 7. Practical measures for live victims are set out in chapter 5. 
of genuine compassion is evident enough, but there should also be recognition of the rights which remain violated and that priority must be given by a state to the redress of those who have suffered at the hands of official agents, as is required by Article 2 of the European Convention on Human Rights ${ }^{94}$ and as is readily recognised by the South African Truth and Reconciliation Commission: ${ }^{95}$

"...it must be said that those with the most power to abuse must carry the heaviest responsibility. It is a matter of the gravest concern when the state, which holds the monopoly on public force and is charged with protecting the rights of citizens, uses that force to violate those rights."

The responsibility of government for human rights abuses in Northern Ireland may not be on the scale of the former regimes in Chile or South Africa, but it is not negligible.

\section{TOWARDS ANALYSIS}

\section{Governance}

The first observation on all of these trends is that we seem to be placing ourselves within the best traditions of late modernity ${ }^{96}$ by uncovering some familiar patterns. One is the pattern of fragmentation - the breaking down of traditional categories and boundaries, in this case judicial and non-judicial as well as legal and political. The second point is that these wider bounds of the application of justice take us into the realms of "governance" rather than government, as a wider array of techniques are applied in order to control and make accountable the state in time of emergency: 97

"Governance signifies a change in the meaning of government, referring to a new process of governing; or a changed condition of ordered rule; or the new method by which society is governed."

Governance is concerned with a complex pattern of interrelationships between social institutions and individuals and the use of a wide array of public/private, local/national/international, institutional/informal responses which move away from hierarchically and juridico-politically

94 See McCann v UK, App. no.18984/91, Ser A vol.324, (1996) 21 EHRR 97. States are under international obligations are placed on states to suppress terrorism, UN GA Res 40/61 (1985), but are not required to give the same guarantee of suppression as in relation to their own agents: $X v$ Ireland, Appl. no.6040/73, (1973) 16 YB 388; Wv UK, Appl. no.9348/81, (1983) 32 DR 190; $X v U K$, Appl. no.9825/82, (1985) 8 EHRR 49; $M v U K$ and Ireland, Appl. no.9837/82, (1986) 47 DR 27.

95 Final Report, vol.1 chap.4 para.80.

96 A. Giddens, The Consequences Of Modernity (Cambridge: Polity Press, 1990).

97 R.A.W. Rhodes, "The New Governance: Governing without Government," (1996) XLIV Political Studies 652 at 652-653. See also J. Kooiman, (ed.), Modern Governance (London: Sage, 1993); J. Hoffman, Beyond the State (Cambridge: Polity Press, 1995); P. Hirst, and G. Thompson, "Globalization and the Future of the Nation State" (1995) 24 (3) Economy and Society 408; G. Teubner, Global Law without a State (Aldershot: Dartmouth, 1997); R.A.W. Rhodes, Understanding Governance: Policy Networks, Governance, Reflexivity, and Accountability (Buckingham: Open University Press, 1997). 
based models. ${ }^{98}$ We seem to recognise some of these trends here, though perhaps more mutedly than with other areas of state activity, even other areas of policing, presumably because of the centrality of security to attributes such as authority, legitimacy and sovereignty.

Building upon these concepts, I argued in a paper in the Columbia Journal of Transnational Law that, when pursuing the principles of constitutional governance, that task can only be achieved by all branches of the state, judicial, executive and legislative in combination, whereas, to date, too much faith has been placed in judicial mechanisms and too little attention has been given to intervention by the legislature and other political mechanisms. ${ }^{99}$ But what I am now contending is that the boundaries between these branches may be more fluid than previously pictured. On the one hand, non-lawyers have a significant role to play in the development of traditional legal business - the goal of justice between two parties. On the other hand, lawyers emerge as surprisingly important players in areas outside their traditional stamping grounds. It used to be possible to say that the presence of "policy" considerations effectively ruled out judges and lawyers. It is true that their presence tends to rule out court-based adjudication because of a number of factors. One is that it makes it difficult to formulate rules for their guidance. Another is that it renders participation by the parties less meaningful, since the adjudicator may have to base decisions on considerations of policy which have not been revealed to those affected. A second reason would be that the issues arising are so wide-ranging and polycentric that allowing them to be disputed would make litigation unmanageable. But the point of this paper is that traditional adjudication does not exhaust the involvement and values of lawyers, so they may still play a valuable role in issues which are indeed policy-oriented.

\section{Feeling at home with governance}

The next question is how should, on the one hand, lawyers, including judges, working in unfamiliar and politically fraught territory and, on the other hand, non-lawyers working within justice acquit themselves?

For the lawyers and judges, there are certainly dangers and difficulties. At one level, one might perhaps draw some lessons from the reflections of two decades ago on the development of public law litigation in the United States. For example, Professor Abram Chayes explained how this took the lawyers far away from the familiar territory of private adjudication and required such features as the activist shaping of the suit by the court and not just the parties, predictive and proactive fact-finding, and more dynamic and forward-looking relief. ${ }^{100}$ In this way, "litigation becomes an explicitly political forum and the courts a visible area of the political process." 101 But this public law litigation should not make the judges indistinguishable from politicians, and so it is vital to reflect upon those techniques or attributes which comprise the core worth of the lawyerly

98 B. Jessop, "The Regulation Approach, Governance and Post-Fordism: Alternative Perspectives on Economic and Political Change ?" (1995) 24 (3) Economy and Society 307 at p 317.

99 C.P. Walker, "Constitutional Governance and Special Powers Against Terrorism" (1997) 35 Columbia Journal of Transnational Law 1.

100 A. Chayes, "The Role of the Judge in Public Law Litigation" (1976) 89 Harvard Law Review 1281. These developments can of course be related to the economic and social development of the state: M.J. Damaska, The Faces of Justice and State Authority (Yale: Universities Press, 1986).

${ }^{101}$ A. Chayes, "The Role of the Judge in Public Law Litigation" (1976) 89 Harvard Law Review 1281 at p.1304. 
way. These include: insulation from narrow political pressures; reflective and dispassionate analysis based on fact as well as increased consistency and certainty, since the judicial method is to proceed on the basis of established rules and precedents; $;{ }^{102}$ narrow rather than wide applications of policy, participation by those affected; and a clear and non-bureaucratic response to those affected. ${ }^{103}$ Openness in process and result are also important. The lawyer should be able to explain in rational terms, whether based in precedent or some other form of relevant argument, what has been decided. The fear that candour might somehow inhibit the process of good decision-making, an excuse against transparency to which executives the world over fiercely cling, ${ }^{104}$ should not infect the practices of lawyers who are asked to step into executive territory. So, openness should be reflected both in process, with the holding of inquiries in public and in the widest possible invitation to participate, and also in outcome, with fully argued and published findings.

The implications for the lawyers who are to be to some extent politically commodified when asked to become involved at some level in solving the problems of emergencies is that if their input is to remain distinct and valued, then they must retain lawyerly attributes. The point of using a lawyer is lost if they become true politicians like the Prime Minister, Tony Blair. ${ }^{105}$ Therefore, reflection is needed upon legal techniques and ethics, not social science and politics. At the same time, this reinforcement of lawyerly attributes will not mask the political role, for in these kinds of tasks "technical virtuosity has never been a guarantee of acceptable performance". ${ }^{106}$ Inevitably, there will be doubts about legitimacy and authority when non-elected lawyers are used in more political roles.

Another lesson which suggests itself is that lawyers should be aware of what is being asked and to realise that the tasks are not the same as courtbased litigation. Clearly, to treat these more political tasks in the same way as private litigation would run into significant problems of justiciability. Of course, it is arguable that no issue is inherently justiciable and no authoritative test exists for isolating matters which should be placed before judges. ${ }^{107}$ Therefore, one is again thrown back upon what advantages or difficulties flow from judicial scrutiny, as discussed earlier and whether any can still be relevant where it is impossible to translate a

102 Prentis v. Atlantic Coastline Co. 211 U.S. 210 (1908) at pp.226-227.

${ }^{103}$ A. Chayes, "The Role of the Judge in Public Law Litigation" (1976) 89 Harvard Law Review 1281 at pp.1307-1308.

${ }^{104}$ See Code of Practice on Access to Government Information (1994, http://www.open.gov.uk/m-of-g/codete.htm) Exemption 2 ("Internal discussion and advice") and Your Right to Know: The Government's proposals for a Freedom of Information Act (London: Cm 3818, Stationery Office, 1997) para.3.12.

105 Prime Minister Blair read Law at Oxford University, was called to the Bar at Lincoln's Inn in 1976, and practised as a barrister until 1983; he entered Parliament in 1983 and became Labour Party leader in 1994: http://www.labour.org.uk/information/index.html.

${ }^{106}$ A. Chayes, "The Role of the Judge in Public Law Litigation" (1976) 89 Harvard Law Review 1281 at p.1315.

${ }^{107}$ See: G. Marshall, "Justiciability" in Guest, A.G. (ed.), Oxford Essays in Jurisprudence (Oxford: Oxford University Press, 1961); R.S. Summers, "Justiciability" (1963) 26 Modern Law Review 530; L.L. Fuller, "The Forms and Limits of Adjudication" (1978) 92 Harvard Law Review 353; J.S. Bell, Policy Arguments (Oxford: Clarendon, 1983). 
desired policy into "sufficiently clearly defined standards to operate the judicial process efficiently by keeping discretion within narrow limits." 108.

There are also guidelines for the non-lawyers, and one might especially emphasise such lawyerly concerns as respect for rights and due process and attention to individual cases. As an example of how not to proceed, one might cite the case of the Runciman Commission, which, mainly consisting of non-lawyers, was asked to suggest reforms to avoid further miscarriages of justice. Its Report has been widely criticised, especially because it was not adequately grounded in researched history or, more seriously, principle. ${ }^{109}$ This absence of principled argument was a wasted opportunity for civic education. Even more dangerous in the short-term, it left the field of reform fairly free for political choice. If the Report's findings were based on little more than either a sincerely held belief or a "contingent fact" 110 arising from a research study, it was always open to a politician to challenge them on an equally sincerely held belief or perhaps to trump them on the basis of further empirical research. Thus, the Commission left itself very open to being overruled or "cannibalized"111 because of its mode of decision-making. This weakness was not an inherent design fault in either the personnel or terms of reference of the Commission which meant that the entire process was a charade or that recommendations unpalatable to the Home Office were out of bounds or could never conceivably be implemented. Nevertheless, the publication of the Report coincided with the advent of a period of attempted populist repression by the Home Office, which found the Report to be suitably malleable for its purposes to achieve its own agenda without having to snub the Commission.

\section{Trends in governance and society}

Turning to other possible implications of these trends in governance and society, the wider use of judges and lawyers in the resolution of the problems caused by political emergency should not develop into an exercise of the wholesale juridification of political issues. For example, the Good Friday Agreement was not an exegesis by Senator Mitchell on the orange and green shades of meanings of "self-determination" within the context of Northern Ireland. ${ }^{112}$ That would be to apply purely legal solutions. Rather, the emphasis is upon legal skills not legal solutions the political commodification of lawyering not law. Of course, juridification of political controversies in other contexts might happen to some extent through the Human Rights Act 1998 in due course. However, the Act has been designed in a decidedly conservative fashion (including the omission of Article 13 and limited judicial powers to strike down

108 Stevens, R.B., "Justiciability - The Restrictive Practices Court Re-examined" [1964] Public Law 227 at p.237.

109 See C.P. Walker, "Miscarriages of justice in principle and practice" in C.P. Walker, and K. Starmer, Miscarriages of Justice: A Review of Justice in Error (London: Blackstone Press, 1999) chap.2.

110 A. Ashworth, The Criminal Process: An Evaluative Study (Oxford: Clarendon Press, 1994) at p. 115.

${ }^{111}$ S. Field, and P.A. Thomas, (eds.), Justice and Efficiency (1994) Journal of Law \& Society 21(1) (special issue, London: Blackwell,) at p.7

112 British Irish Agreement reached in the multi-party negotiations (London: Cm.3883, Stationery Office, 1998). Indeed, the Agreement is almost entirely political in nature, since it cites no precedents or evidence for its conclusions and has a preamble (a "Declaration of Support") consisting of just six very short paragraphs. 
legislation $\left.{ }^{113}\right)$. Conversely, Article 15 is expressly mentioned and is to allow the government to "derogate" from its obligations to respect rights. This provision is currently in use in Northern Ireland to allow the detention of terrorist suspects for seven days without any judicial authorisation and so perpetuates the response to the Brogan judgment. ${ }^{114}$ The derogation will continue (it is designated under section 14 and Schedule 2) for a further five years without any need for interim review or renewal under the 1998 Act.

Perhaps a better explanation than juridification is that the spread of lawyering is part of a republican movement in society - a move to republican justice whereunder decision-making depends less on personal or institutional authority than on involvement and full citizenship. ${ }^{115}$ Lawyers are well placed to organise and represent in achieving the constraint (of "parsimony") that the onus of proof is against state intervention and also the need to check established state power. This republican approach has several less palatable features propounded by at least some of its proponents, ${ }^{116}$ including the exclusionary emphasis upon "citizenship" (or, on a more localised basis, "community"117) and the willingness to promote state intervention (often in the form of surveillance) to protect the ill-defined "province of others", which may encourage intervention on the basis of vague notions of "anti-social conduct" such as appear in the Crime and Disorder Act 1998. However, it does chime with some of the features found in relation to emergency situations and may be a policy now moving forward into local democracy, as signalled by a recent Department of the Environment paper. ${ }^{118}$ Of course, the link between republicanism and legalism in these senses is not a new idea. More than a century and a half ago, de Tocqueville identified the strong links between lawyers and republican virtue:119

"The profession of the law is the only aristocratic element which can be amalgamated without violence with the natural elements of democracy....I cannot believe that a republic could subsist if the influence of lawyers in public business did not increase in proportion to the power of the people."

${ }^{113}$ Human Rights Act 1998 s.4 ("Declarations of incompatibility"). See further Lord Irvine, "Judges and decision makers" 1996 Public Law 59.

${ }^{114}$ Application Nos. 11209/84, 11266/84, 11386/85, Ser.A. 145 B, (1989) 11 EHRR 117.

115 J. Braithwaite, and P. Pettit, Not Just Deserts: A Republican Theory of Criminal Justice (Oxford: Oxford University Press, 1990) p.9. See also J. Braithwaite, "Inequality and Republican Criminology" in J. Hagan and R.D. Peterson, (eds.), Crime and Inequality (Stanford University Press, 1995); N. Lacey, and L. Zedner, "Discourses of community in criminal justice" (1995) 22 Journal of Law and Society 301; J.W. Raine, and M.J. Wilson, "Beyond managerialism in criminal justice" (1997) 36 Howard Journal 80

116 But other versions more reassuring depict communitarianism as not only consistent with the enjoyment of individual rights but as a necessary condition: A. Etzioni, The Spirit of Community (London: Fontana, 1995) pp.x, 15.

117 A. Crawford, The Local Governance of Crime (Oxford: Clarendon Press, 1997) chaps. 5,8 .

${ }^{118}$ Modernising Local Government (Department of the Environment, 1998). See further C. Walker, and Y. Akdeniz, "Virtual democracy" [1998] Public Law p 489.

119 A. de Tocqueville, De la Democratie en Amerique (London: Saunders \& Otley, 1835) vol.i chap. 16. 
It is perhaps ironic that as the ideals of law within the executive sphere seems to be gaining ground, their practice within the heartland of the legal system is coming under attack because of the cost to the public purse. ${ }^{120}$ This inconsistency should serve as a useful reminder not to overtheorise British constitutional customs, which usually owe much more to happenstance than foggy French theorists.

${ }^{120}$ See Lord Chancellor's Department, Striking the Balance: The Future of Legal Aid in England and Wales (London: Cm 3305, Stationery Office, 1996) chap.3; D. Wall, "Legal aid, social policy and the architecture of criminal justice" (1996) 23 Journal of Law \& Society 549; R. Young and D. Wall, Access to Justice (London: Blackstone Press, 1996); Lord Chancellor's Department, Modernising Justice (London: Cm.4155, Stationery Office, 1999). 